\title{
Evaluating Suppliers/Consultants and Procuring Entities in the Landscape of Public Procurement in Bangladesh
}

\author{
Shahidul Islam ${ }^{1}$ \\ ${ }^{1}$ Procurement Consultant, Second Local Governance Support Project (LGSP-II), Local Government Division \\ Ministry of Local Government, Rural Development and Cooperatives, Bangladesh \\ Correspondence: Shahidul Islam, Procurement Consultant, Second Local Governance Support Project (LGSP-II), \\ Local Government Division Ministry of Local Government, Rural Development and Cooperatives, Bangladesh. \\ E-mail: md.si.shahid@gmail.com
}

Received: September 5, 2017

Accepted: September 11, $2017 \quad$ Online Published: October 25, 2017

doi:10.5539/emr.v6n2p54

URL: http://doi.org/10.5539/emr.v6n2p54

\begin{abstract}
Developing professionalism in procurement, both in Public as well as in Private Sectors, is a challenge in the field of Public Procurement in Bangladesh. This paper discusses on application of Public Procurement Rules in Government Sector with an objective to develop a transparent, accountable and efficient procurement aiming at value for money with sustainable development in Bangladesh. Finally the study strives to identify the bottlenecks in implementing Public Procurement Rules in Bangladesh.
\end{abstract}

Keywords: Public Procurement Rules, Public Procurement ACT, Procuring Entities (PE), Suppliers (Sup.), Consultants (Con.), Challenges, best value for money, transparency, accountability and quality

\section{Introduction}

Public procurement is one of a number of activities within the operations of the Government of the People's Republic of Bangladesh that requires special attention in promoting good corporate governance and better overall value for money.

Measuring the Effect of capacity of Suppliers/Consultants and the procuring entities in successful implementation of Public Procurement Rules has always been an effective role for organizations and corporations. Increasing the effectiveness, efficiency and transparency of public procurement systems is an on-going concern of governments in Developing Countries and the international development community. Moreover, in most Developing Countries public procurement of goods, services and works accounts for a significant proportion of GDP, so improved public procurement capacity results in greater value for money and increased public service delivery.

Strong procurement management in the public sector is a tool for achieving political, economic and social goals. In the area of diminishing resources and increased demand for accountability and transparency in government, the "stakeholders/shareholders" of the public sector are demanding more effective and efficient use of public resources.

Present study is aimed to conduct a systematic study and evaluation of existing public procurement process of Government of Bangladesh and to develop considerable suggestions for sustainable development about public procurement in Bangladesh.

\section{Literature Review}

This research is to gain effective implementation and ensure an open, transparent and compliant process in Public Procurement within the suppliers/consultants and procuring entities. Effort will also be made to analyze the possibilities of continuous improvement on all categories of expenditure, work in partnership with the private sector and other organizations, i.e., suppliers/consultants to achieve value for money, quality and effective service delivery, promote innovation and equal opportunity for all businesses through a transparent and fair public sector procurement process.

This research will closely looks into what value for money is and how we can achieve it. In addition we will also look why suppliers/consultants and procuring entities should work in partnership and how they can work 
together in the context of public procurement. Finally it is expected to work on how we can build professionalism among the suppliers/consultants and procuring entities.

\section{Methodology}

Contributor's observation, case study and paper based questionnaires technique of Survey Method have been used to collect primary data from Procurement personnel of Procuring Entities like Local Government Engineering Department (LGED), Bangladesh Institute of Management, Local Governance Support Project, Department of Agriculture Extension, Directorate of Primary Education.

Bangladesh Agricultural Research Institute, Bangladesh Agricultural Development Corporation, Bangabandhu Sheikh Mujibur Rahman Agricultural University, Bangladesh Rice Research Institute, Department of Social Services, Directorate of Secondary and Higher Education, Directorate of Primary Education and Directorate of Technical Education, etc. Suppliers and Consultants related with the public procurement process were surveyed by individual questionnaires. Qualitative outcomes, from this long study were incorporated in developing of questionnaires.

These are the following steps that were followed in developing of questionnaires:

(a) Based on definition of the fact to be investigated, data requirements were fixed and qualitative outcomes from case study and contributor observation were integrated.

(b) Closed and open ended questionnaires were decided.

(c) Three sets questions were developed for this study.

(d) Matter of questionnaires were summarized and questions were written on two areas for each set of question; one general information and another being specific information.

(e) Questionnaires were pre-tested by the field to know how well to work.

(f) After pretest of questionnaires, final versions were completed to ensure that the questionnaires are ready for application.

(g) Finally the questionnaires were prepared to complete it dependable and applicable realistic check lists were considered for this study to do an acceptable job.

Questionnaire technique of survey method was used to collect primary data from the Procurement Personnel of Procuring Entities in Public Sector. Random sampling method was used to select 50 nos. participants (20 nos. from procuring entities, 15 nos. from suppliers and another 15 nos. from consultants) who were engage in public procurement process.

Total 20 queries of each set questions for Procuring Entities and Suppliers and 19 queries were developed only for consultants for assessment of supplier/consultants and procurement personnel of Procuring Entities in the landscape of public procurement.

\section{Discussion}

\subsection{Statistical Status of Respondents}

Demographic data and statistical status of respondents for general information are as below:

Table 1. Educational qualification of respondents

\begin{tabular}{cccccccc}
\hline \multirow{2}{*}{ Sl. No. } & Level of education & \multicolumn{3}{c}{ No. of respondent } & \multicolumn{3}{c}{ Percentage (\%) } \\
\cline { 3 - 8 } & & Procuring Entity & Supplier & Consultant & Procuring Entity & Supplier & Consultant \\
\hline 1 & MPhil/Phd & 1 & 0 & 0 & 5 & 0 & 0 \\
2 & CA & 0 & 0 & 1 & 0 & 0 & 6.66 \\
3 & Masters & 17 & 7 & 13 & 85 & 46.67 & 86.67 \\
4 & Bachelors & 2 & 8 & 1 & 10 & 53.33 & 6.67 \\
\hline
\end{tabular}

Table 1 shows that Masters level completed persons as major resource, i.e., $85 \%$ of Procuring Entities and $86.67 \%$ of Consultants involved in the Public Procurement Process, whether only $46.67 \%$ suppliers are of Masters level that are involved in this process. 
Table 2. Length of experience of respondents

\begin{tabular}{cccccccc}
\hline \multirow{2}{*}{ Sl. No. } & Length of Exp. & \multicolumn{3}{c}{ No. of respondent } & \multicolumn{3}{c}{ Percentage (\%) } \\
\cline { 3 - 7 } & & Procuring Entity & Supplier & Consultant & Procuring Entity & Supplier & Consultant \\
\hline 1 & $1-5$ Years & 3 & 1 & 2 & 15 & 6.66 & 13.33 \\
2 & $6-10$ Years & 7 & 4 & 5 & 35 & 26.67 & 33.34 \\
3 & 11 and Above Years & 10 & 10 & 8 & 50 & 66.67 \\
\hline
\end{tabular}

Table 2 shows that majority of the participants had experience of more than 10 years, from all the three types of organizations, i.e., Procuring Entities, Suppliers and Consultant involved in the public procurement process.

Table 3. Position within the organization of respondents of suppliers and consultants

\begin{tabular}{cccccc}
\hline \multirow{2}{*}{ S1. No. } & \multirow{2}{*}{ Position } & \multicolumn{2}{c}{ No. of respondent } & \multicolumn{2}{c}{ Percent age (\%) } \\
\cline { 3 - 6 } & & Supplier & Consultant & Supplier & Consultant \\
\hline 1 & Proprietor & 7 & 3 & 46.66 & 20 \\
2 & Representative & 8 & 12 & 53.34 & 80 \\
\hline
\end{tabular}

Table 3 shows that majority of the participants are representatives of the organizations, $53.34 \%$ for the suppliers, and $80 \%$ for the consultants.

Table 4. Position within the organization of respondents of procurement personnel

\begin{tabular}{llcc}
\hline Sl. No. & \multicolumn{1}{c}{ Position } & No. of respondent & Percentage (\%) \\
\hline 1 & Government Official & 14 & 70 \\
2 & Consultant & 6 & 30 \\
\hline
\end{tabular}

Table 4 shows that survey was conducted with major participation of Government officials, i.e., $70 \%$, the other part being the consultants (30\%).

\subsection{Experimental Outcomes from the Specific Questionnaires Implemented on Selected Respondents}

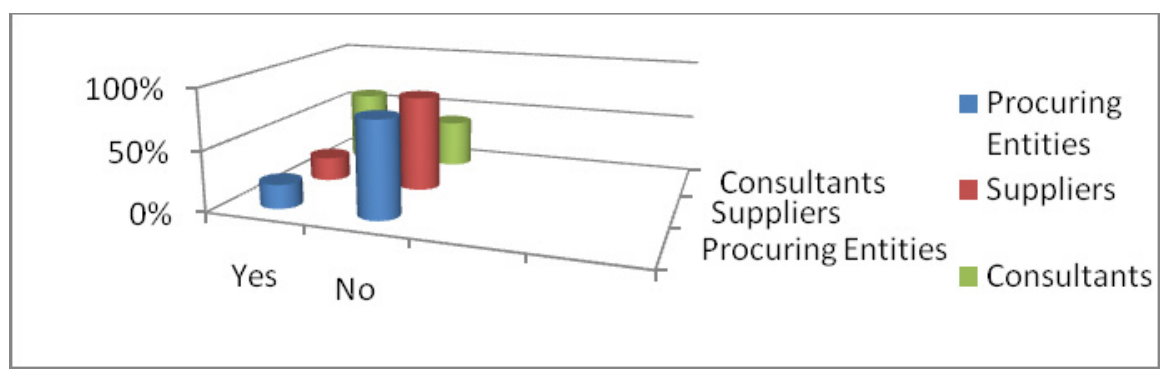

Figure 1. Analytical representation on implementation of e-tendering process in public procurement system

Majority of Procuring Entities do not use e-GP (80\%); only 20\% uses e-GP, who felt comfort with the training given. On the other hand majority $(80 \%)$ of the Suppliers did not have experience on e-GP but the majority of Consultants had the experience on e-GP (60\%), $77.77 \%$ of whom do feel fully comfort about the training given to them on e-GP system.

Astonishingly all of the respondents of Procuring Entities, Suppliers/Consultants were found interested about e-GP. 


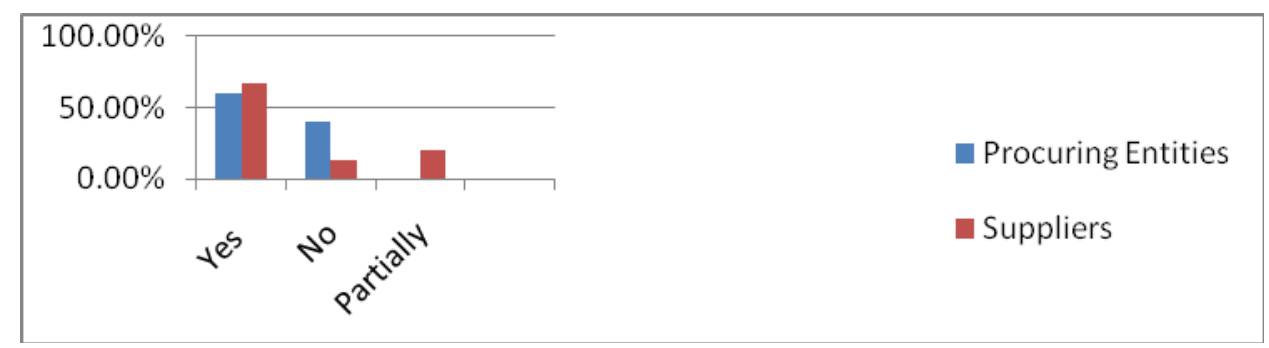

Figure 2. Graphical representation shows the obstructions on selling/purchasing and receiving/dropping tenders in the public procurement process

The Procuring Entities should take more care and appropriate arrangements to handle the obstruction in tendering process.

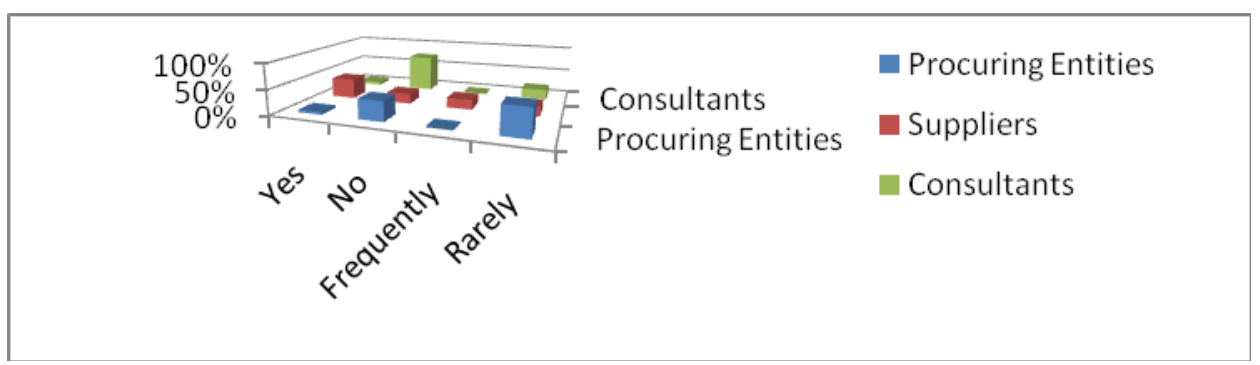

Figure 3. Comparative analysis on the Corrupt/Coercive/ Fraudulent/Collusive Practice by Procuring Entities/Suppliers/Consultants

The response and perception varied considerably. It needs close \& appropriate attention.

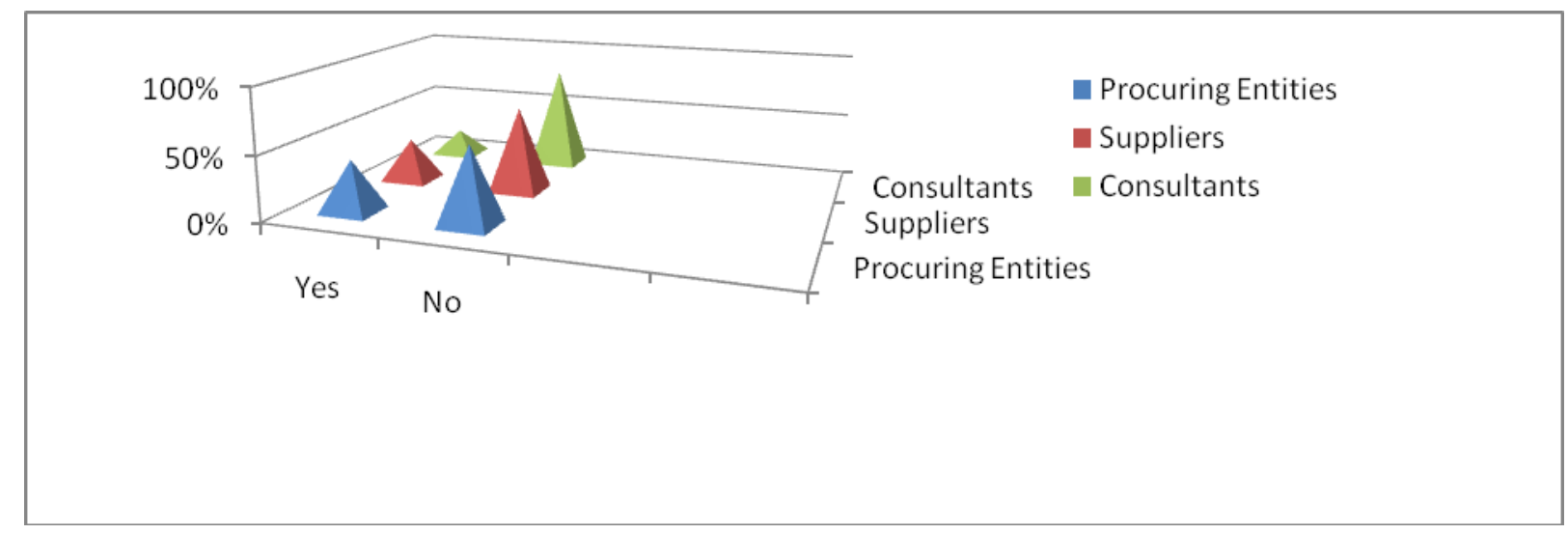

Figure 4. Analytical presentation on requirements of training in public procurement

The graph shows the requirement of both basic \& refreshers training on public procurement for all concerned. 


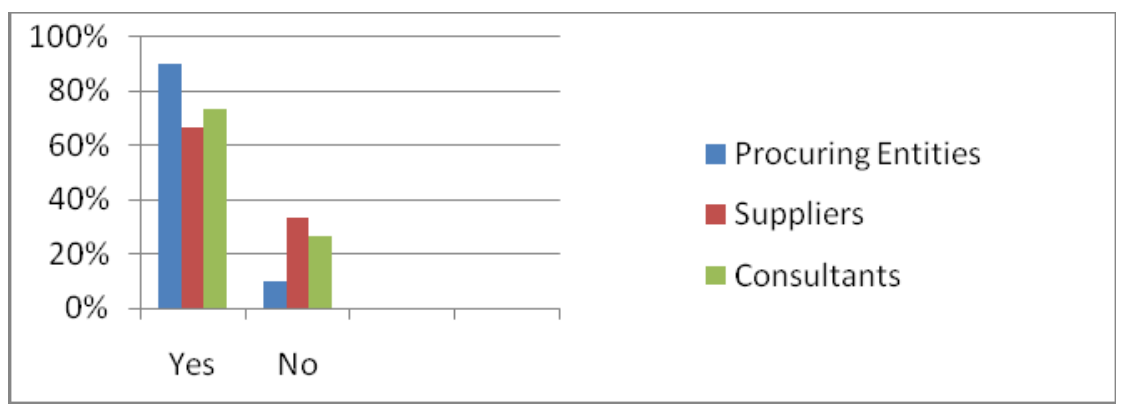

Figure 5. Graphical representation on capacity assessment status of procurement personnel

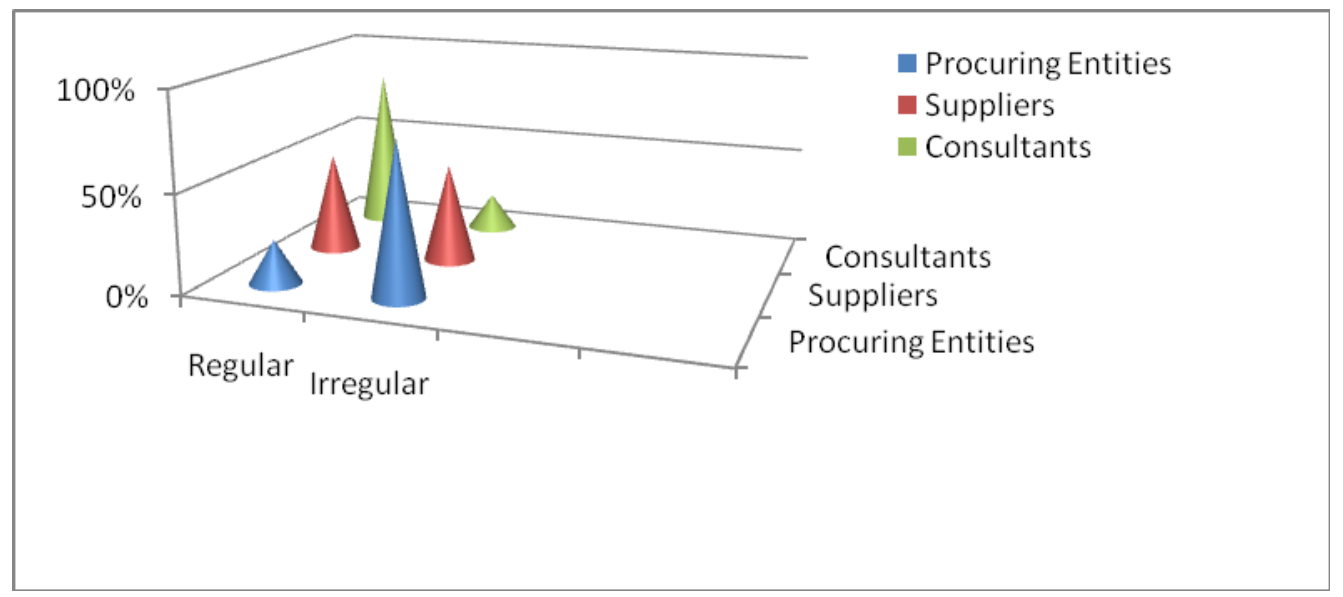

Figure 6. Graphical representation on capacity assessment style of procurement personnel

Figures 5 and 6 show that Procuring entities are irregular in doing assessment whereas the consultants are reverse but the suppliers are equivocal.

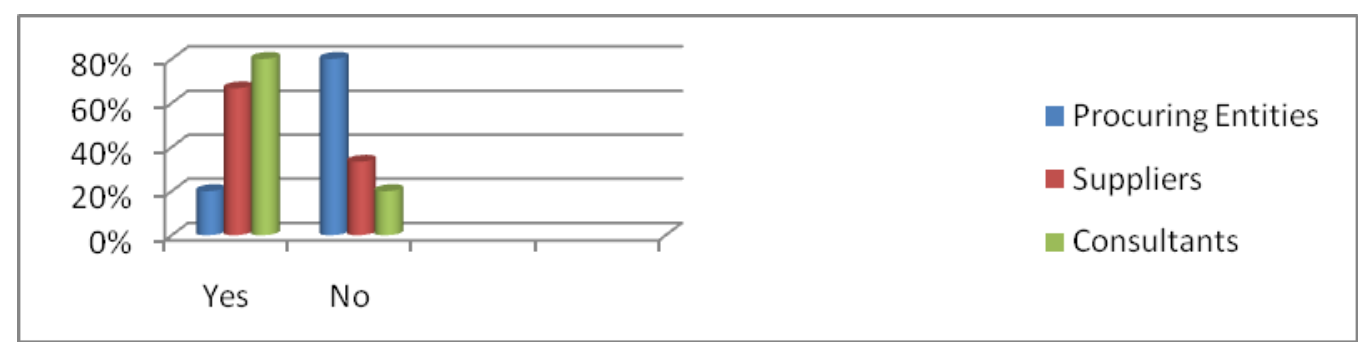

Figure 7. Graphical representation on measurement of performance of concern personnel in public procurement process

The consultants are the best in doing performance assessment, suppliers being next and very close but the procuring entities lags too behind. 


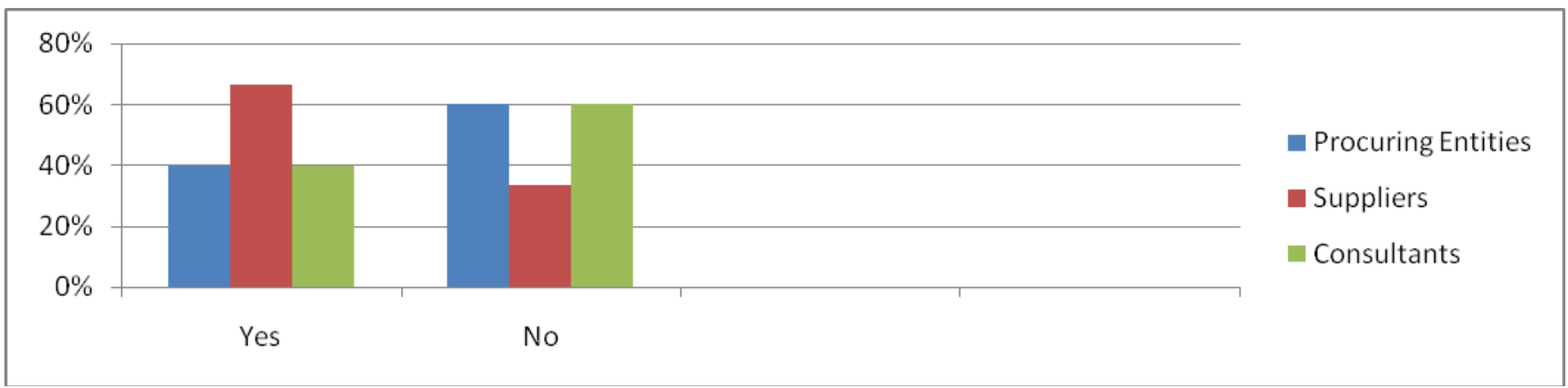

Figure 8. Graphical representation on operation of contract management cell by the procuring entities, supplier and consultants

The graph shows that the most of the suppliers do have contract management cells in their organizations, whereas the most of the procuring entities as well as the consultants lack equally cells in their organizations. But in the survey, all were found interested in setting up of Contract Management Cell in their respective organizations.

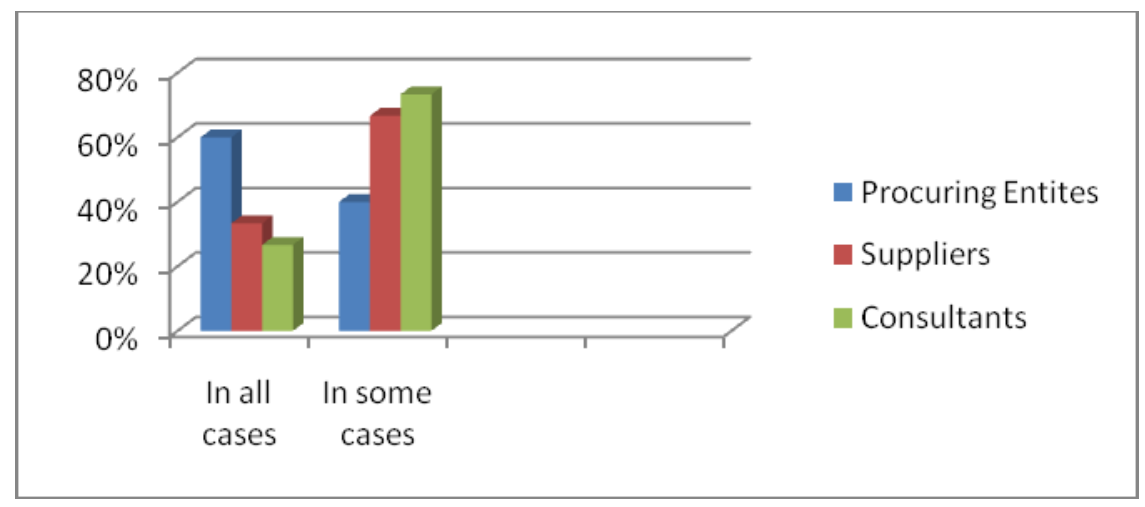

Figure 9. Graphical representation shows that invitation status of pre-tender/pre-proposal meeting in the tendering process

The procuring entities invite pre-tender/pre-proposal meetings more frequently whereas the suppliers think that they do it only in some cases, but according to the consultants it is even lesser. 


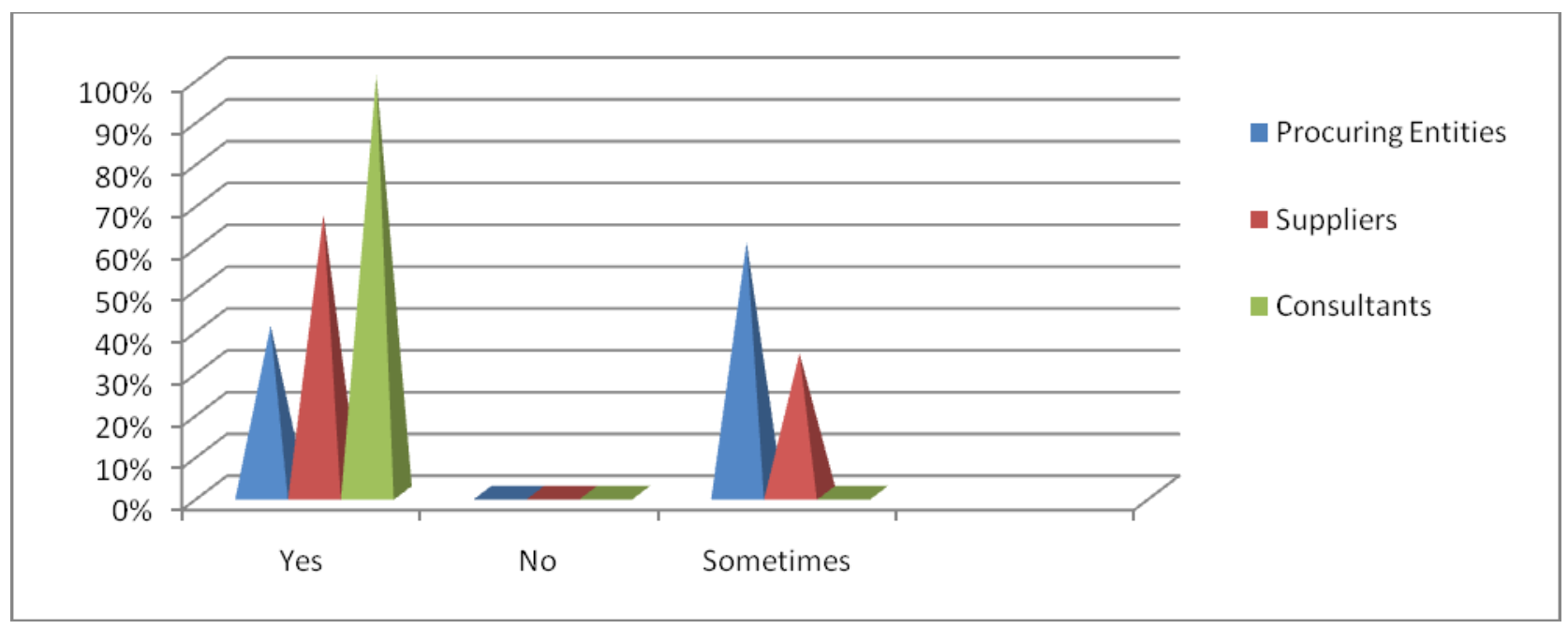

Figure 10. Graphical representation shows that attendance status in thepre-tender/pre-proposal meeting by the representative of procuring entities, suppliers and consultants

In the view of Procuring Entities, Suppliers and consultants sometimes attend the pre-tender/pre-proposal meetings, whereas the Suppliers demand that they attend in most of the cases. The consultants are sanguine that they attend almost in all cases.

In Figures 9 and 10, all of the respondents opine that pre-tender/pre-proposal meeting is useful for efficient procurement process.

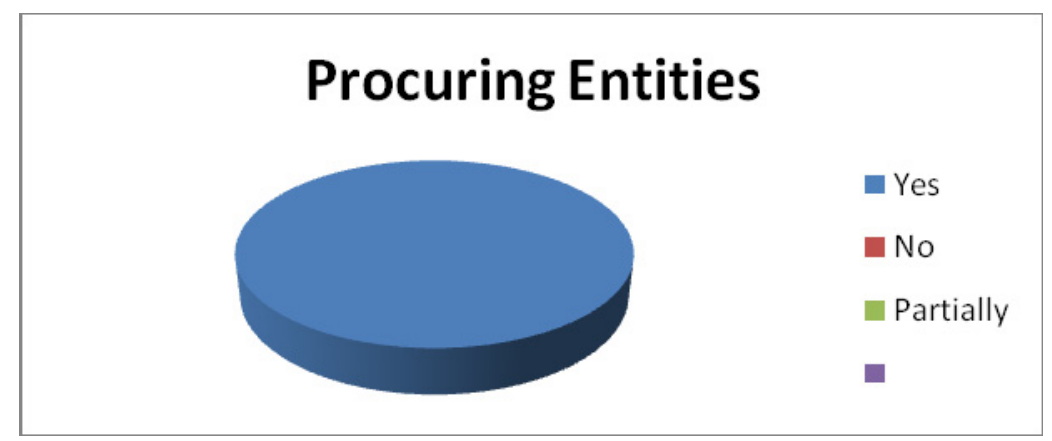

Figure 11. Graphical representation on preparation of tenders/proposals by Suppliers and consultants in the judgment of procuring entities

Graph shows that the Procuring Entities are of the opinion that the Supplies and consultants do feel comfortable in preparing tenders/proposals. 


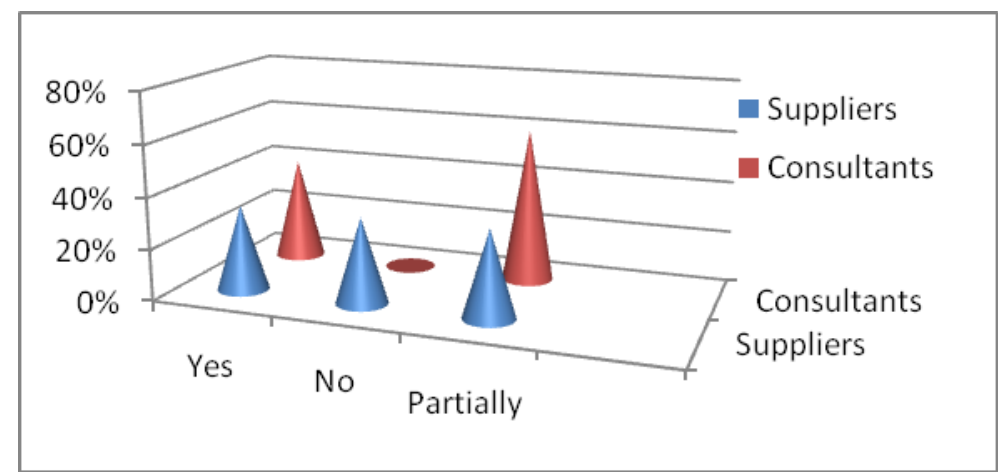

Figure 12. Comparative analysis on preparation of tenders/proposals by suppliers/consultants

The suppliers were found divided equally in three groups who feel comfortable, not comfortable at all, and others partially comfortable, whereas the consultants are mostly partially comfortable and only some feel comfortable.

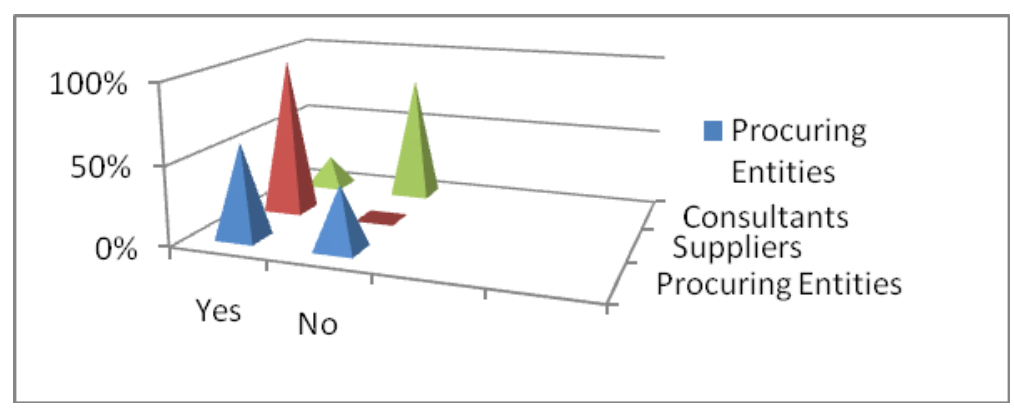

Figure 13. Comparative analysis on re-submission oftenders/proposals

The Procuring Entities divided and majority not sure on the issue of re-submission of tender documents/RFPs, whereas the suppliers did not know the actual provision, but the consultants are in good scenario, where mostly are of the opinion that it do not need to be re-submitted.

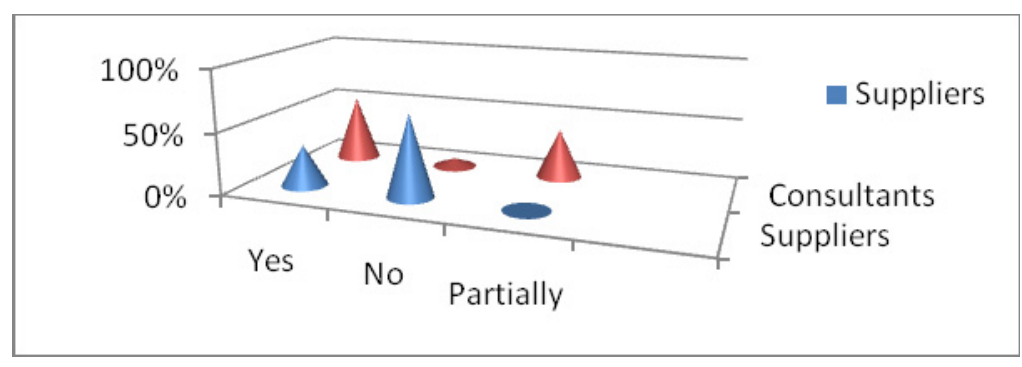

Figure 14. Graphical representation on Corporate Social Responsibly

The graph shows that the Consultants mostly have policy on their Corporate Social Responsibly (CSR), either fully or partially, whereas the Suppliers, mostly do not have it, though in cases they do have their CSR. 


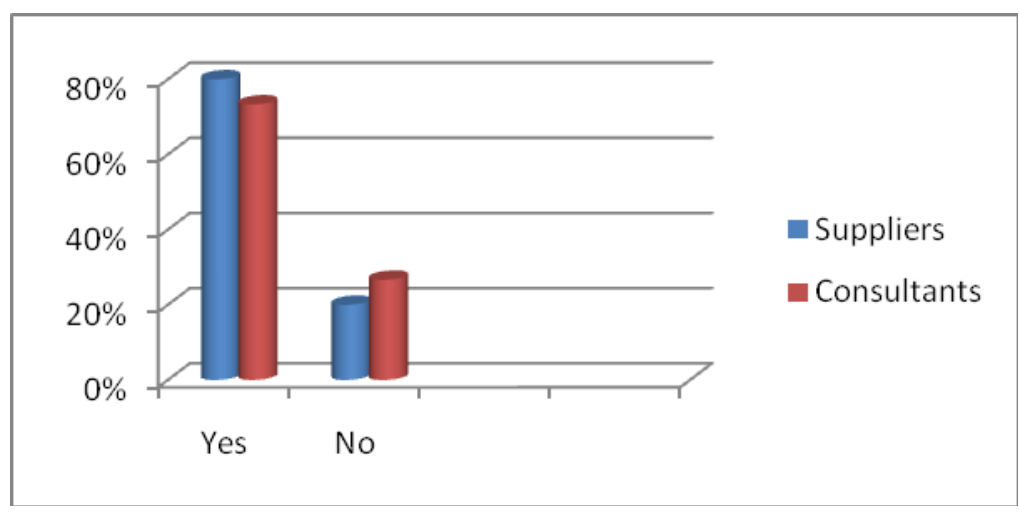

Figure 15. Analysis on difficulty/ambiguity/omission/contradiction in the Tender/Proposal documents

Graph shows that the both the Suppliers and Consultants find difficulty/ambiguity/omission/contradiction in the Tender/Proposal documents.

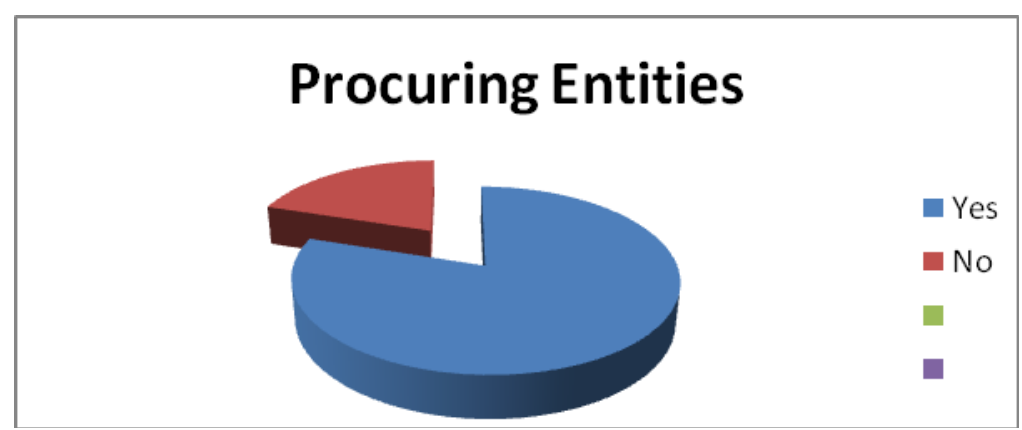

Figure 16. Graphical representation on conduct market survey before finalizing specifications/TORs \& or cost estimates

The graph shows that most of the respondents $(80 \%)$ of procuring entities conduct market survey before finalizing specifications/TORs \& or cost estimates

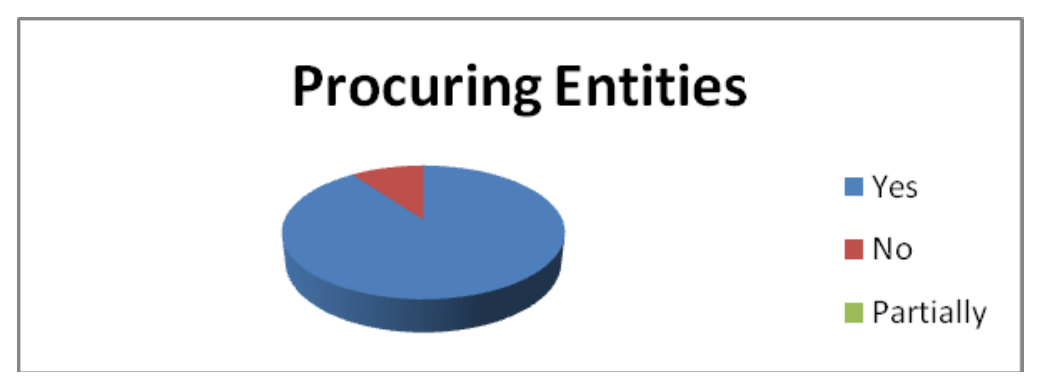

Figure 17. Graphical representation on importance of market survey before finalizing specifications/TORs \& or cost estimates

The graph shows that $90 \%$ respondents agreed that market survey is essential for better procurement. 


\section{Procuring Entities}

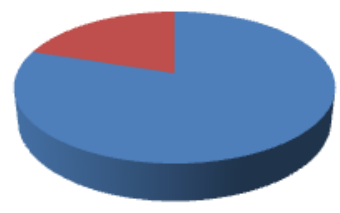

Figure 18. Analytical presentation on preparation/revision procurement plan in team (under revenue budget)

Graph show that $20 \%$ procurement personnel under revenue budget do not prepare/revise procurement plan in teams.

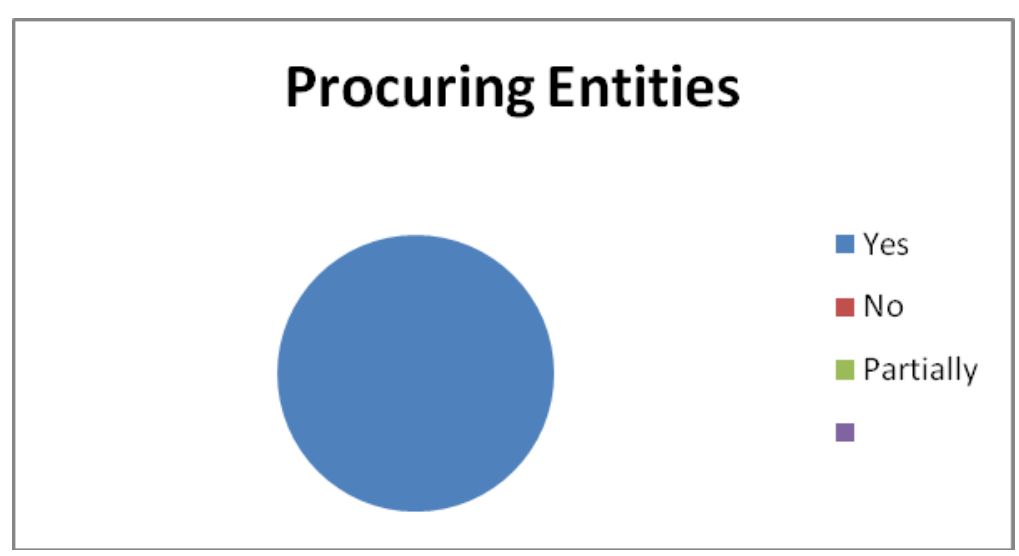

Figure 19. Analytical presentation on preparation/revision procurement plan in team (under development budget)

Graph show that $100 \%$ procurement personnel under development budget prepare/revise procurement plan in team.

\section{Conclusions}

Based on the experiment evaluating the Suppliers, Consultants and Procuring Entities in the landscape of public procurement, the following recommendations are made:

(a) e-GP is strongly recommended as all the Procuring Entities, Suppliers and Consultants are interested in it as e-GP could be a solution to perception of corrupt, coercive, obstructive, fraudulent or collusive practices by procuring entities or the Suppliers/Consultants. (b) Basic Training for procurement personnel of all the Procuring Entities as well as that of Suppliers and Consultants should be ensured and be refreshed on regularly. (c) Performance of concerned personnel of all the Procuring Entities needs to measured on regular basis to increase the efficiency in Public Procurement; this may also be introduced for the Suppliers/Consultants who do not practice it. (d) Managing Contracts by a dedicated Cell within Procuring Entities as well as Suppliers \& Consultants should be put into practice for smooth implementation of agreements established. (e) Holding pre-tender or pre-proposal meetings should be encouraged in applicable cases in order to eliminate chances of ambiguities, omissions, conflicts in Tender documents or Request for Proposal documents to make the procurement hassle free. (f) The Suppliers or Consultant, who do not have policy on their Corporate Social Responsibility, should be made aware of it by the appropriate authority or regulatory body. (g) Procuring Entities should carry out market survey before finalizing specifications TORs \& cost estimates in order to avoid any ambiguity, omission or conflict in the specifications or TORs \& cost estimates. (h) Officials involved in procurement under revenue budget should also be made equally conscious in Procurement Planning as they were found less aware of it.

While assessing effectiveness of public procurement in Bangladesh, it's vital to put into action a number of good practices. Among these, good practices reflecting efficiency, transparency, accountability and fair competition 
boosting market economy to achieving value for money needs to be institutionalized. As a research work and as per tactical analysis and procedure of the research, there may have some off-center facts \& findings. So, creative ideas are always respected.

\section{References}

Amy, D. A., Anu, S., \& Andrea, M. (n.d.). Supplier Self-Assessment Questionnaire (Saq): Building the Foundation for Sustainable Supply Chains. Director, Corporate Program, Ceres.

Collins, A. (2012). Public Procurement In Ghana: The Implementation Challenges To The Public Procurement Law 2003 (Act 663). International Journal of Construction Supply Chain Management.

CPTU, IMED, GOB. (2010a). Public Procurement Regulations 2008. Government of Bangladesh.

CPTU, IMED, GOB. (2010b). Public Procurement ACT 2006. Government of Bangladesh.

Geo, Q. (n.d.). Research report on the feasibility of specific legislation for National Treasury's newly established Office of the Chief of the Chief Procurement Officer. DFC S.A.U.

Johanna, M. (2012). Measuring the Effectiveness of Publicprocurement. Hamk University of Applied Science.

John, T. F. (2008). Standard Operating Policies and Procedures for Public Procurement. Neimacro Group Consortium.

Kamruzzaman. (2012). Sustainable Procurement: Scope and Practice in the Public Sector in Bangladesh. Institute of Governance Studies, Brac University.

Kirsten, R., Ejlskov, J., \& Marie, L. R. (n.d.). Procurement Capacity Development: From Theory to Practice. United Nations Development Programme (Undp).

Lyckle, G. (2014). Government Procurement In Japan Obstacles And Opportunities For European Smes. IEU-Japan Centre.

Mohammad, A. M., \& Zahidul, I. (2013). Evaluatio of Public Procurement Mechanism For Sustainable Development In Bangladesh, Ijret.

Procurement Department of VALE. (2014). Supplier's Code of Ethics, and Conduct, VALE.

United Nations Development Programme (UNDP). (2010). Public Procurement, Capacity Development. Retrieved from https://www.unpcdc.org

United Nations Environment Programme (UNEP). (n.d.). Division of Technology, Industry and Economics (DTIE) Economics and Trade Branch (ETB), Ways to Increase the Effectiveness of Capacity Building for Sustainable Development. United Nations Environment Programmme.

\section{Copyrights}

Copyright for this article is retained by the author(s), with first publication rights granted to the journal.

This is an open-access article distributed under the terms and conditions of the Creative Commons Attribution license (http://creativecommons.org/licenses/by/4.0/). 